\title{
PENGARUH DIET EKSTRAK BUAH SALAM (Syzygium polyanthumr [Wight.] Walp) TERHADAP KADAR GLUKOSA DARAH DAN PROFIL LIPID (TOTAL KOLESTEROL, HDL-C, LDL-C, DAN TRIGLISERIDA) PADA TIKUS WISTAR
}

\author{
EFFECT OF SALAM (BAY) (Syzygium polyanthum [Wight.] Walp) FRUIT EXTRACT DIET \\ TOWARD BLOOD GLUCOSE LEVEL AND LIPID PROFILE (TOTAL CHOLESTEROL, \\ HDL-C, LDL-C AND TRIGLYCERIDES) ON WISTAR MICE
}

\author{
Setyaningrum Ariviani ${ }^{1)}$ \\ 1) Staf Pengajar Jurusan Ilmu dan Teknologi Pangan, Fakultas Pertanian, \\ Universitas Sebelas Maret, Surakarta
}

\begin{abstract}
Previous study indicated that salam (bay) (Syzygium polyanthum [Wight.] Walp) fruit extract had antioxidant capacity as both free radical scavenger and inhibitor of linoleic system per oxidation. The aims of the research were to examine effect of salam (bay) (Syzygium polyanthum [Wight.] Walp) fruit extract diet toward blood glucose level and lipid profiles (total cholesterol, $H D L-C, L D L-C$ and Triglycerides) on Wistar mice. The results indicated that salam (bay) fruit extract diet decreased blood glucose level, total cholesterol, triglycerides, cholesterol LDL, and increased cholesterol HDL level of wistar mice, consecutively i.e. 5,92\%, 8,10\%, 4,51 $\%, 48.25 \%$ and $11.87 \%$.
\end{abstract}

Keywords : antioxidant, blood glucose level, diet, lipid profiles, salam (bay) fruit extract

\section{ABSTRAK}

Penelitian sebelumnya menunjukkan bahwa ekstrak buah salam (Syzygium polyanthum [Wight.] Walp) memiliki kapasitas antioksidan sebagai penangkap radikal bebas dan penghambat peroksidasi sistem linoleat. Penelitian ini bertujuan untuk mengkaji pengaruh diet ekstrak buah salam (Syzygium polyanthum [Wight.] Walp) terhadap kadar glukosa darah dan profil lipid (total kolesterol, HDL-C, LDL-C dan Trigliserida) pada tikus wistar. Hasil penelitian menunjukkan bahwa diet ekstrak buah salam dapat menurunkan kadar glukosa, total kolesterol, trigliserida, LDL kolesterol, dan meningkatkan kadar HDL kolesterol tikus wistar, bertutut-turut sebesar 5,92\%, $8,10 \%, 4,51 \%, 48.25 \%$ dan $11.87 \%$.

Kata kunci : antioksidan, diet, ekstrak buah salam, kadar glukosa darah, profil lipid

\section{PENDAHULUAN}

Beberapa dekade yang lalu buah salam banyak dikonsumsi oleh anak-anak di pedesaan di kabupaten Bantul tanpa menimbulkan efek keracunan. Salam (Syzygium polyanthum [Wight.] Walp) dapat ditemukan di daerah dataran rendah sampai ketinggian 1.400 meter di atas permukaan laut. Buahnya buah buni, bulat berdiameter 8$9 \mathrm{~mm}$, buah muda berwarna hijau, setelah masak menjadi merah gelap (keunguan), Salam ditanam untuk diambil daunnya sebagai pelengkap bumbu dapur, sedangkan kulit batang, akar dan buah juga berkhasiat sebagai obat (Dalimartha, 2006). Penelitian sebelumnya memperlihatkan bahwa ekstrak buah salam memiliki kapasitas antiradikal (DPPH) dan penghambatan peroksidasi sistem linoleat terkait dengan kandungan antosianinnya.

Antosianin merupakan pigmen yang bertanggungjawab terhadap warna merah, ungu dan biru pada buah-buahan, sayuran, dan beberapa seralia. Antosianin merupakan kelompok terbesar senyawa fenolik yang memperlihatkan aktivitas antioksidan tinggi, yang mempengaruhi oksidasi LDL dan pangan berlemak (Satué-Gracia and others 1997; Fukumoto and Mazza 2000; Smith and others 2000). Antosianin mampu memberikan perlindungan terhadap beberapa penyakit degeneratif (Mazza 2000; Smith and others 2000). Perhatian terhadap pigmen antosianin intensif dalam beberapa tahun terakhir ini karena manfaatnya bagi kesehatan, seperti mengurangi resiko penyakit jantung koroner, mengurangi resiko 
stroke, aktivitas antikarsinogen, efek antiinflammatory, memperbaiki ketajaman mata, dan memperbaiki perilaku kognitif. Peranan ini terkait dengan kapasitas antioksidan antosianin yaitu merupakan penangkap radikal yang efektif (R.E. Wrolstad, 2004).

James Joseph and others (1999) menggambarkan bahwa daya ingat dan perilaku kognitif tikus tua bisa diperbaiki dengan suplementasi pakan dengan ekstrak blueberry dan strawberry yang kaya antosianin. Studi klinis di Italia memperlihatkan bahwa $79 \%$ dari pasien diabetes yang mengkonsumsi ekstrak bilberry (160 mg duakali sehari selama 1 bulan) menunjukkan peningkatan diabetic retinopathy pada akhir percobaan (Perossini and others 1987).

Produk oksidasi lemak pada makanan yang dikonsumsi dapat mempercepat terjadinya luka dan memulai proses aterogenesis (Addis et al., 1983 dalam Raharjo, 2004). Terjadinya penyakit jantung koroner melalui tiga fase, yaitu tahap inisiasi yang ditandai terjadinya luka pada lapisan endothelium pembuluh darah, tahap propagasi terjadinya penimbunan kolesterol akibat luka yang terjadi pada tahap inisiasi sehingga menimbulkan plaque yang bisa menyumbat aliran darah, tahap terminasi yang ditandai terjadinya thrombosis, kerusakan otot jantung (Addis and Park, 1989). Dampak negatif produk oksidasi lemak ini dapat diminimalisasi dengan meningkatkan status sistem antioksidatif tubuh melalui konsumsi makanan sumber antioksidan.

Produk oksidasi lemak yang masuk ke dalam tubuh bersama-sama makanan akhirnya berada dalam lipoprotein dalam plasma darah (Addis, 1990). Lipoprotein merupakan kompleks lemak dan protein yang secara umum berfungsi sebagai alat transport lemak ke seluruh bagian tubuh manusia. Lipoprotein dapat diklasifikasi berdasarkan densitasnya yaitu kilomikron, very low density lipoprotein (VLDL), intermediate density lipoprotein (IDL), low density lipoprotein (LDL), dan high density lipoprotein (HDL). Kolesterol ester merupakan komponen LDL dalam jumlah terbanyak (42.2\%), hal ini menjadikan LDL rentan terhadap oksidasi. Dalam satu molekul LDL terdapat berbagai jenis asam lemak. Setengah dari asam lemak tersebut merupakan polyunsaturated fatty acid (PUFA) yang sangat rentan terhadap oksidasi (Esterbaue, et al., 1991). Akumulasi kolesterol di dalam makrofag tidak akan terjadi bila LDL tidak teroksidasi (Heinecke, 1987 and Steinberg et al., 1989 dalam Raharjo, 2004).

Penelitian ini mengkaji pengaruh diet ekstrak buah salam (Syzygium polyanthum [Wight.] Walp.) terhadap kadar glukosa darah dan profil lipid (total kolesterol, HDL kolesterol, LDL kolesterol, dan trigliserida) tikus wistar diberi pakan standar AIN 93 modifikasi dengan susu lactona skim sebagai sumber protein

\section{BAHAN DAN METODE}

Bahan:

- Penelitian ini menggunakan hewan percobaan tikus jenis wistar jantan dengan berat antara 200 gram - 239 gram sebanyak 6 ekor yang dibagi menjadi dua kelompok yaitu kontrol dan perlakuan diet ekstrak buah salam dengan perincian sebanyak 3 ekor (3 ulangan) untuk masing-masing perlakuan.

- Pakan tikus yang digunakan dalam percobaan ini mengacu pada diet basal tikus yaitu AIN 93 yang dimodifikasi. Bahan yang dibutuhkan yaitu pati jagung, susu Lactona skim (sebagai sumber protein, sukrosa, mineral dan vitamin), minyak kedelai.

- Diet perlakuan menggunakan ekstrak buah salam.

- Bahan kimia yang digunakan untuk analisis adalah reagen untuk analisa dengan kualitas pro analisa, meliputi: kit untuk analisa glukosa (GOD-PAP), kit HDL, kit trigliserida (GPO) kit kolesterol (CHOD PAP), diperoleh dari Laboratorium Gizi Pusat Studi Pangan dan Gizi UGM.

\section{Alat:}

Kandang tikus dan perlengkapannya, seperangkat alat pengambil spesimen darah, seperangkat alat untuk analisa glukosa, kolesterol, trigliserida, HDL dan LDL, neraca analitik, spektrofotometer, sentrifuge 


\section{Metode}

\section{Penyiapan Pakan}

Penyiapan

pembuatan pakan

berdasarkan AIN 93 yang dimodifikasi, sebagai sumber protein digunakan susu lactona skim dengan komposisi sebagai berikut: Protein $37 \%$, lemak 1\%, Karbohidrat 51,3\%, mineral 7,7\%. Komposisi pakan yang digunakan dalam penelitian ditabulasi dalam Tabel 1.

Tabel 1. Komposisi pakan AIN modifikasi

\begin{tabular}{|l|c|}
\hline $\begin{array}{l}\text { Komposisi pakan AIN 93 } \\
\text { modifikasi per 1000 gram }\end{array}$ & Jumlah (gr) \\
\hline Lactona skim & 460 \\
Pati jagung & $629-236=393,5$ \\
Minyak & $70-4,6=65,4$ \\
\hline Total & 918 \\
\hline
\end{tabular}

Teknik pembuatan pakan adalah sebagai berikut: semua bahan ditimbang sesuai formula (Tabel 1.), dicampur rata kemudian ditambahkan sedikit air sampai bisa dibentuk. Kemudian dimasukkan ke dalam ekstruder hingga dihasilkan massa padat dengan bentuk pilinan-pilinan panjang yang kemudian dipotong kecil-kecil lalu dikeringkan pada suhu $\pm 50^{\circ} \mathrm{C}$ selama 4 jam sehingga diperoleh pakan kering. Pemberian pakan dilakukan setiap pagi hari sebanyak 15 gr per ekor.

\section{Penyiapan Perlakuan Diet Menggunakan Ekstrak Buah Salam}

Diet diberikan dua kali sehari (pagi dan sore hari) secara force feeding sebanyak $0,3 \mathrm{ml}$ per hari per tikus (masing-masing pemberian sebanyak 0,15 ml). Ekstrak buah salam dibuat dengan perbandingan 1:1 terhadap daging buah salam, kemudian ekstrak disimpan di cool room $\left(4^{0} \mathrm{C}\right)$ (Ariviani, 2007)

\section{Pemeliharaan Hewan Coba}

Enam ekor tikus jantan jenis wistar dimasukkan ke dalam kandang individual secara tertutup dengan kondisi cahaya terkontrol, ventilasi udara dalam kandang cukup, suhu udara pada suhu kamar. Tikus diberi pakan dan air minum setiap pagi hari secara ad libitum. Tikus dibagi dalam dua kelompok, kelompok kontrol tanpa pemberian ekstrak buah salam dan kelompok perlakuan yang diberi tambahan diet ekstrak buah salam. Kandang dibersihkan setiap hari, sisa pakan ditimbang setiap hari sebelum kandang dibersihkan. Berat badan tikus ditimbang setiap dua hari sekali.

\section{Pengambilan Sampel Darah}

Sampel darah diambil secara reorbital plexus (melalui pembuluh darah yang terdapat di ujung mata) selama pelaksanaan penelitian. Pengambilan darah dilakukan pada hari ke-1 sebelum perlakuan dan hari terakhir (hari ke-7).

\section{Analisa}

Analisa darah dilakukan pada awal sebelum perlakuan dan pada akhir perlakuan, meliputi: analisa kadar kolesterol dilakukan dengan metode enzimatic colorimetric test "CHOD-PAP" (Allain, et al.,1997), HDL metode presipitasi LDL, VLDL dan chylomikron (Rhicmond,1973, Eckel et al.,1997), trigliserida ditentukan dengan metode Colorimetric enzymatic test "GPO" (McCowan et al.,1983), glukosa dianalisis dengan menggunakan metode enzimatic colorimetric test "GOD-PAP" (Barham \& Trinder,1972).

Prosedur kerja secara keseluruhan dapat dilihat pada Gambar 1 berikut.

Tikus Wistar Jantan (6 ekor)

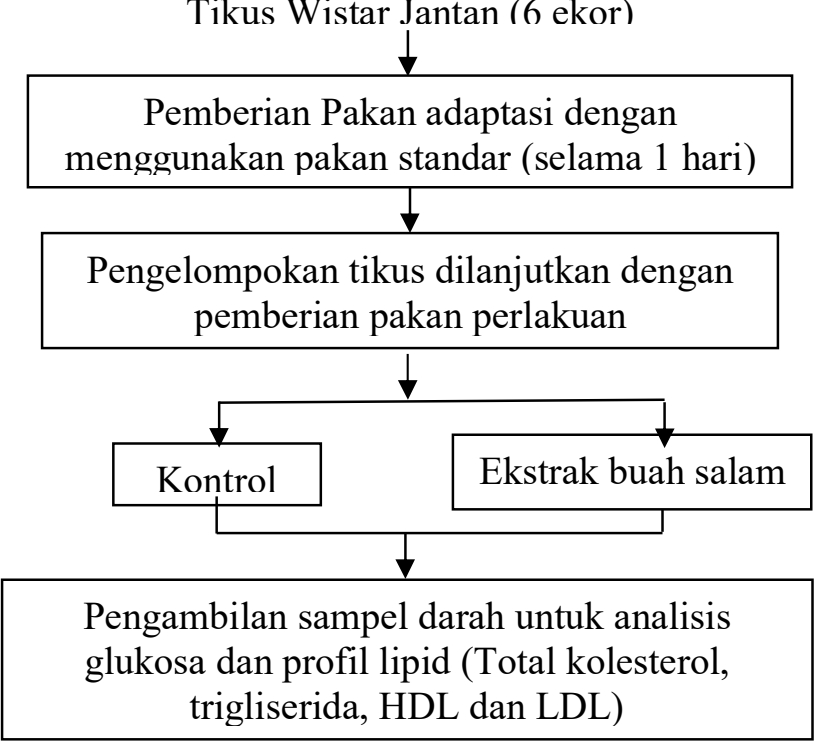

Gambar 1. Skema prosedur kerja penelitian 


\section{HASIL DAN PEMBAHASAN}

\section{Berat Badan Tikus}

Berat badan tikus diamati tiap dua hari sekali dengan melakukan penimbangan bobot. Data berat badan tikus dari semua perlakuan ditampilkan pada Tabel 2.

Tabel 2. Berat badan tikus (gr) Selama Percobaan

\begin{tabular}{|c|c|c|c|c|}
\hline Perlakuan & \multicolumn{4}{|c|}{ Berat Badan Tikus (gr) } \\
\hline Kontrol & $\begin{array}{c}\text { Hari } \\
\text { ke-1 }\end{array}$ & $\begin{array}{c}\text { Hari } \\
\text { ke-3 }\end{array}$ & $\begin{array}{c}\text { Hari } \\
\text { ke-5 }\end{array}$ & $\begin{array}{c}\text { Hari } \\
\text { ke-7 }\end{array}$ \\
\hline 1 & 167 & 172 & 173 & 174 \\
2 & 209 & 219 & 220 & 222 \\
3 & 211 & 216 & 225 & 228 \\
\hline Rerata & 195.67 & 202.33 & 206.00 & 208.00 \\
\hline Buah salam & & & & \\
\hline 1 & 234 & 235 & 238 & 239 \\
2 & 200 & 215 & 215 & 217 \\
3 & 225 & 228 & 229 & 231 \\
Rerata & 219.67 & 226.00 & 227.33 & 229.00 \\
\hline
\end{tabular}

Berdasarkan data di atas, terlihat adanya kenaikkan bobot tikus selama percobaan baik untuk kelompok kontrol maupun kelompok perlakuan diet ekstrak buah salam. Hal ini didukung oleh data sisa pakan tikus.

Pengamatan sisa pakan tikus dilakukan setiap hari, hasilnya tidak ada pakan tikus yang tersisa. Hal ini mengindikasikan bahwa pemberian diet perlakuan ekstrak buah salam dengan teknik force feeding tidak menimbulkan gangguan pada intake pakan tikus.

\section{Kadar Glukosa Darah}

Data kadar glukosa darah awal dan akhir percobaan ditampilkan pada Tabel 3.

Pada awal percobaan, tikus memiliki kadar glukosa darah pada kisaran 82,30 $\mathrm{mg} / \mathrm{dl}$ sd $87,02 \mathrm{mg} / \mathrm{dl}$. Setelah dilakukan intervensi ekstrak buah salam, terjadi penurunan kadar glukosa darah sebesar $5,92 \%$. Pada kelompok kontrol terjadi peningkatan kadar glukosa sebesar 2,28\%. Hal ini menunjukkan bahwa ekstrak buah salam memiliki potensi hipoglikemia. Diduga kemampuan hipoglikemia tersebut dikarenakan adanya senyawa antosianin dalam buah salam yang berperan sebagai antioksidan. Penurunan glukosa darah berkaitan dengan kemampuan antioksidan dalam mencegah stress oksidatif sehingga dapat mencegah reaksi glikasi non-enzimatik dari plasma protein atau antioksidan dapat menyebabkan regenerasi sel $\beta$. Halliwell dan Gutteride (1999) melaporkan bahwa ROS dapat menimbulkan stress oksidatif yang memicu berkembangnya berbagai penyakit degeneratif misalnya atherosclerosis, hipertensi, diabetes, kanker dan penuaan dini. Stress oksidatif dapat menyebabkan kerusakan jaringan termasuk kerusakan sel $\beta$ yang selanjutnya menimbulkan diabetes.

Tabel 3. Kadar Glukosa Darah Awal dan Akhir Percobaan

\begin{tabular}{|c|c|c|}
\hline Perlakuan & Kadar glukosa darah mg/dl \\
\hline Kontrol & $\begin{array}{c}\text { Awal (hari } \\
\text { ke-1) }\end{array}$ & $\begin{array}{c}\text { Akhir (hari } \\
\text { ke-7) }\end{array}$ \\
\hline 1 & 87.02 & 89.32 \\
2 & 83.48 & 85.84 \\
3 & 85.55 & 86.73 \\
\hline Rata-rata & 85.35 & 87.30 \\
\hline & \multicolumn{2}{|c|}{ Meningkat 2,28\% } \\
\hline Buah salam & 84.37 & 79.65 \\
1 & 82.60 & 77.88 \\
2 & 82.30 & 76.99 \\
3 & 83.09 & 78.17 \\
\hline Rata-rata & \multicolumn{2}{|c|}{ Menurun 5,92\% } \\
\hline \multicolumn{3}{|c}{} \\
\hline
\end{tabular}

\section{Kadar Total Kolesterol dan Kadar Trigliserida Darah}

Pengaruh pemberian diet ekstrak buah salam terhadap kadar total kolesterol dan kadar trigliserida dapat dilihat pada Tabel 4.

Berdasarkan data pengamatan, diketahui bahwa kadar total kolesterol dan kadar trigliserida tikus yang diberi perlakuan diet ekstrak buah salam menurun, rata rata penurunannya adalah $8,10 \%$ untuk total kolesterol dan 4,51\% untuk trigliserida. Sedang pada kontrol, kadar total kolesterol dan kadar trigliserida mengalami peningkatan yaitu masing-masing sebesar 7,92 \% dan 7,16 $\%$. Hal ini juga dikarenakan senyawa antosianin dalam buah salam yang merupakan senyawa antioksidan yang memiliki kemampuan free radical scavenging yang kuat.

Mekanisme penurunan kolesterol oleh antioksidan dalam penelitian ini ada dua kemungkinan. Kemungkinan pertama, penurunan kolesterol merupakan konsekuensi 
Tabel 4. Kadar Total Kolesterol dan Kadar Trigliserida Darah Tikus

\begin{tabular}{|c|c|c|c|c|}
\hline \multirow{2}{*}{ Kode } & \multicolumn{2}{|c|}{ Kadar total kolesterol mg/dl } & \multicolumn{2}{|c|}{ Kadar Trigliserida mg/dl } \\
\hline & Awal (hari ke-1) & Akhir (hari ke-7) & Awal (hari ke-1) & Akhir (hari ke-7) \\
\hline \multicolumn{5}{|l|}{ Kontrol } \\
\hline 1 & 101.20 & 107.57 & 75.28 & 83.39 \\
\hline 2 & 102.79 & 112.35 & 78.06 & 79.70 \\
\hline 3 & 107.57 & 116.33 & 75.28 & 81.92 \\
\hline Rata-rata & 103.85 & 112.08 & 76.21 & 81.67 \\
\hline & \multicolumn{2}{|c|}{ Meningkat 7,92\% } & \multicolumn{2}{|c|}{ Meningkat 7,16\% } \\
\hline \multicolumn{5}{|l|}{ Buah salam } \\
\hline 1 & 109.16 & 99.60 & 73.80 & 72.32 \\
\hline 2 & 115.54 & 106.77 & 77.49 & 73.80 \\
\hline 3 & 109.96 & 101.20 & 78.23 & 73.06 \\
\hline Rata-rata & 111.55 & 102.52 & 76.51 & 73.06 \\
\hline & \multicolumn{2}{|l|}{ Men } & \multicolumn{2}{|c|}{ Menurun $4,51 \%$} \\
\hline
\end{tabular}

dari penurunan glukosa darah. Dengan penurunan glukosa darah, Asetyl Co-A dapat masuk ke siklus TCA sehingga ketersediaannya untuk disintesis menjadi kolesterol sangat terbatas. Kemungkinan kedua adalah antioksidan akan menghambat oksidasi LDL dan akumulasi kolesterol di dalam makrofag tidak akan terjadi bila LDL tidak teroksidasi (Heinecke, 1987 and Steinberg et al., 1989 dalam Raharjo, 2004). Mekanisme penurunan Trigliserida (TG) akibat konsumsi antioksidan antosianin buah salam terkait dengan kemampuan antioksidan dalam mempertahankan PUFA. Jika PUFA tinggi maka TAG plasma akan turun.

\section{Kadar LDL Kolesterol Darah}

Pengaruh pemberian diet ekstrak buah salam terhadap kadar LDL kolesterol dapat dilihat pada Tabel 5. Berdasarkan Tabel 5 tersebut terlihat bahwa kadar LDL tikus dengan diet perlakuan turun sebesar 48,25\% dan pada kontrol terjadi peningkatan $34,23 \%$.

Penurunan LDL kolesterol pada tikus yang diberi perlakuan diet ekstrak buah salam kemungkinan merupakan akibat tidak langsung terkait dengan ketersediaan PUFA. Adanya antosianin ekstrak buah salam yang memiliki kapasitas sebagai antioksidan akan melindungi atau menjaga ketersediaan PUFA di dalam darah, hal ini dapat mendorong terbentuknya mLDL (PUFA akan mengkonversi LDL menjadi mLDL) yang dapat dikenali oleh scavenger receptor yang terdapat dalam liver, sehingga LDL kolesterol dapat ditarik ke liver. Akibatnya LDL kolesterol darah turun. Kemungkinan lain, adanya peningkatan aktivitas antioksidan dengan penambahan ekstrak buah salam akan meningkatkan aktivitas reseptor di dalam liver yang mengakibatkan lebih banyak kolesterol yang diikat oleh liver sehingga kolesterol darah akan turun.

Tabel 5. Kadar LDL Kolesterol Darah Tikus

\begin{tabular}{|c|c|c|}
\hline \multirow{2}{*}{ Perlakuan } & \multicolumn{2}{|c|}{ Kadar LDL mg/dl } \\
\cline { 2 - 3 } & Awal (hari ke-1) & Akhir (hari ke-7) \\
\hline Kontrol & 24.85 & 32.18 \\
1 & 25.60 & 35.76 \\
2 & 28.00 & 37.37 \\
3 & 26.15 & 35.10 \\
\hline Rata-rata & \multicolumn{2}{|c|}{ Meningkat 34,23\% } \\
\hline \multicolumn{2}{|}{} \\
\hline Buah & 32.47 & 17.39 \\
salam & 34.23 & 17.17 \\
1 & 31.73 & 16.26 \\
2 & 32.81 & 16.98 \\
3 & \multicolumn{2}{|c|}{ Menurun $48,25 \%$} \\
\hline Rata-rata
\end{tabular}

\section{Kadar HDL Kolesterol}

Berdasarkan Tabel 6 ini diketahui bahwa pemberian diet ekstrak buah salam akan meningkatkan kadar HDL kolesterol darah, sebesar $11,87 \%$, sedang pada kontrol tanpa pemberian diet ekstrak buah salam terjadi penurunan kadar HDL kolesterol darah sebesar 3,41\%. Hal ini juga dikarenakan kandungan antioksidan 
antosianin dalam buah salam. Antioksidan berperan dalam pemblokiran respon HDL, sehingga HDL akan meningkat.

Tabel 6. Kadar HDL Kolesterol Darah Tikus

\begin{tabular}{|c|c|c|}
\hline \multirow{2}{*}{ Kode } & \multicolumn{2}{|c|}{ Kadar HDL mg/dl } \\
\cline { 2 - 3 } & Awal (hari ke-1) & Akhir (hari ke-7) \\
\hline Kontrol & \multicolumn{2}{|c|}{} \\
1 & 61.29 & 58.71 \\
2 & 62.58 & 60.65 \\
3 & 64.52 & 62.58 \\
\hline Rata-rata & 62.79 & 60.65 \\
\hline \multicolumn{2}{|c|}{ Menurun 3,41\% } \\
\hline Buah & \multicolumn{2}{|}{} \\
salam & 61.94 & 67.74 \\
1 & 65.81 & 74.84 \\
2 & 62.58 & 70.32 \\
3 & 63.44 & 70.97 \\
\hline Rata-rata & \multicolumn{2}{|c|}{ Meningkat $11,87 \%$} \\
\hline \multicolumn{2}{|c}{}
\end{tabular}

\section{KESIMPULAN}

Diet ekstrak buah salam dengan teknik force feeding tidak menurunkan intake pakan tikus, hal ini didukung dengan data peningkatan berat badan tikus baik pada perlakuan kontrol maupun diet yang mengalami peningkatan seiring waktu penelitian.

Perlakuan diet ekstrak buah salam dapat menurunkan kadar glukosa darah, kadar total kolesterol, kadar trigliserida dan kadar LDL darah tikus wistar berturut-turut sebesar 5,92\%, 8,10\%, 4,51\%, dan 48.25\%. Diet ekstrak buah salam ini juga diketahui mampu meningkatkan kadar HDL darah tikus sebesar $11.87 \%$.

\section{DAFTAR PUSTAKA}

Abuja, P. M., Murkovic, M., Pfannhauser W. 1996. Antioxidant and prooxidant activities of elderberry (Sambucus nigra) extract in low-density lipoprotein oxidation. J Agric Food Chem 46:4091-6

Addis, P. B. and Park., S W. 1989. Role of lipid oxidation products in atherosclerosis, In: Food. Toxicology, Scanlan, R. A., Taylor, S. L., (eds), New York: Marcel dekker Inc., 297 330
Addis, P. B. 1990. Corronary heart disesse: An update with emphasis on dietary lipid oxidation products. Free Radical Biol. Med., 7: 179

Allain,C.C., Poon,L.S., Chan,C.S.G., Ricchmond,W. And Fu, P.C., 1974. Enzymatic Determination of total serum cholesterol.Clin Chem,20:470.

Ariviani, S., Ishartani, D., 2007. Kajian Aktivitas Antioksidan Buah Salam (Syzygium polyanthum [Wight.] Walp.). Laporan Penelitian Doden Muda. Fakultas Peranian UNS, Solo.

Barham, D. and Trinder, P.1972. An Improved Color Reagent for Determination of Blood Glucose by the Oxidase System.Analyst 97:142145.

Boff, J., Min, D.B. 2002. Chemistry and reaction of singlet oxygen in foods. Comp Rev Food Sci Saf 1:58-72.

Cohen, J. H., Kristal , A. R., Stanford, J. L. 2000. Fruit and vegetabel intakes and prostate cancer risk. J Natl Cancer Inst 92:61-8.

Dalimartha, S. 2006. Atlas Tumbuhan Obat Indonesia. dalam www.pdpersi.co.id.

Esterbauer, H., Rotheneder, M. D., Striegl, G., and Wage, G.. 1991. Role of vitamin $E$ in prevention of $L D L$ oxidation. Am. J. Clin. Nutr. 53:3145.

Fukumoto, L. R., Mazza, G. 2000. Assessing antioxidant and prooxidant activity of phenolic compounds. J Agric Food Chem 48:3597-604.

Girotti, A. 1998. Lipid hydroperoxide generation, turnover, and effector action in biological systems. J Lipid Res 39:1529-42.

Hagiwara, A., Yoshino, H., Ichiharam , T., Kawabe, M., Tamano, S., Aoki, H., Koda, T., Nakamura, M., Imaida, K., Ito, N., Shirai, T. 2002. J Toxicol Sci 27:57-68.

Halliwell, B. and Gutteride, J.M.1999.Evaluation of Antioxidant Status in Humans. In: Papas, A.M.(Ed): Antioxidant Status, Diet, Nutrition and Health.CRP Press, Washington,D.C.

Hendrich, S., Wang, G. J., Lin, H. K., Xu, X., Tew, B. Y., Wang, H. J., Murphy, P. 
A. 1999. Isoflavone metabolism and bioavailability. In: Papas AM, editor, Antioxidant status, diet, nutrition, and health. Boca Raton, Fla.: CRC press. p. 211-30.

Joseph, J. A., Shukitt-Hale, B., Denisova, N. A., Bielinski, D. B., Martin, A., McEwen, J. J., Bickford, P. C. 1999. Reversals of age-related declines in neuronal signal transduction, cognitive and motor behavioral deficits with blueberry, spinach, or strawberry dietary supplementation. J Neurosci 19:8114-21.

Mazza, G., Miniati, E. 1993. Anthocyanins in fruits, vegetabels, and grains. Boca Raton, Fla.: CRC Press.

McCowan, M. W., Atiss, J. V., Standbergh, R. and Zak. 1983. A Peroxidasecoupled Methods for Calorimetric Determination of Serum Triglycerides.Clin.Chem.29:538-542.

Packer, L., Weber, S. U. 2001. The role of vitamin $\mathrm{E}$ in the emerging field of nutraceuticals. In: Kramer K, Hoppe PP, Packer L, editors. Nutraceuticals in health and disease prevention. New York: Marcel Dekker. p 27-43.

Perossini, M., Guidi, G., Chiellini, S., Siravo, D. 1987. Studio clinico sull'impeigo degli antocianisidi del miritillo (Tegens) nel trattamento delle microangiopathi retiniche di tipo diabetico ed ipertensivo. Ottal Clin Ocul 113:1173-90.

Raharjo, S. 2004. Kerusakan Oksidatif pada Makanan. Pusat Studi Pangan dan Gizi UGM, Yogyakarta

Satué-Gracia, M.T., Heinonen, M., Frankel, E. N. 1997. Anthocyanins as antioxidants on human low-density lipoprotein and lecithin-liposome systems. J Agric Food Chem 45:336267.

Simon, H. U., Haj-Yehia, A., Levi-Schaffer, F. 2000. Role of reactive oxygen species (ROS) in the apoptosis induction. Apoptosis 5:415-8.

Smith, M. A. L., Marley, K. A., Seigler, D., Singletary, K. W., Meline, B. 2000. Bioactive properties of wild blueberry fruits. J Food Sci 65:352-6.
Wrolstad, R. E. 2004. Anthocyanin Pigments-Bioactivity and Coloring Properties. Journal of Food Science Vol. 69, Nr. 5, C419 - C42. 